\title{
OBITUARIES
}

\section{Manilal Damodar Daya $(1941-2013)$}

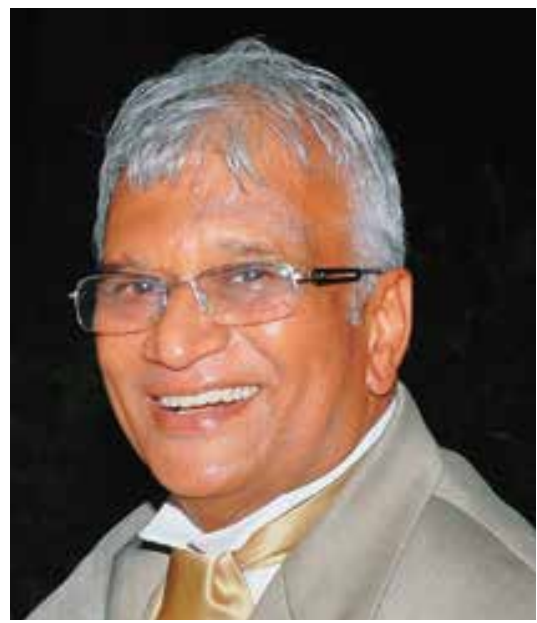

Manilal Damodar Daya was born in South End, Port Elizabeth, in June 1941 of parents who had immigrated to South Africa from Gujarat State in India. He did his schooling in Port Elizabeth, matriculating at South End High School, and completed his MB ChB at the University of Cape Town in 1967. After doing his internship at Somerset Hospital he started work as a medical officer at Livingstone Hospital, Port Elizabeth, in 1969. He married his wife Hemkala in 1971 and they had four boys, two of whom followed in their father's footsteps to become medical doctors.

Mani developed a passion for surgery, and was motivated and encouraged by other specialists to pursue postgraduate studies. He started work as a medical officer in general surgery at Livingstone Hospital in 1978 under one of his mentors, Mr John McQuaide, and obtained the FRCS (Edin) and FRCS (Glasg) in 1978. This was a major achievement, as Livingstone Hospital was not a recognised teaching hospital and Mani had to spend time at Groote Schuur Hospital in Cape Town before being allowed to register as a specialist. $\mathrm{He}$ returned to work as a consultant at Livingstone Hospital and went into private practice in 1984.

I met Mani in 1979 at Livingstone Hospital and was impressed by this unassuming, confident surgeon. He never hesitated to ask colleagues for an opinion and was always prepared to listen and entertain an alternative - a true role model and inspiration during the heady days of apartheid.

Mani was always busy, but always had time for a patient or a friend. His intently calculating and deliberate surgical decision-making was an example to his young colleagues. Our relationship grew from his being my boss to my consultant, my friend, my partner, and finally my brother, mentor and peer. We had a very special relationship, and I always derived solace and strength from his reassuring presence during surgery.

Mani's unhesitating willingness to help whenever he was asked, be it to do clinics and emergency calls at state hospitals, or become an ATLS and basic surgical skills instructor or a journal club presenter, represented the most admirable example of altruism, selflessness and goodness.

Mani remained an ardent supporter and member of the Association of Surgeons of South Africa, SURGICOM and the South African Medical Association throughout his career. He was SAMA Eastern Cape President in 2010, and was honoured with the SAMA Life Membership award in 2011.

Rest in peace, Mani - the surgical fraternity of South Africa will miss a truly exemplary surgeon, peer and role model.

Hambe kahle mhlobo wam. Slaap rustig, die Baai se kind en Afrika se seun.

\section{Sats S Pillay}

Head, Department of Surgery, University of Limpopo (Polokwane Campus), Limpopo, South Africa

Past Head, Department of Surgery, Port Elizabeth Metropole Hospitals, Eastern Cape, South Africa

livsurg@global.co.za 